\title{
KEMITRAAN PEMERINTAH DAERAH DENGAN KELOMPOK MASYARAKAT DALAM PENGELOLAAN HUTAN MANGROVE DI DESA TONGKE-TONGKE KABUPATEN SINJAI
}

\author{
Raman $^{1}$, Ihyani Malik², Hamrun ${ }^{1}$ \\ 1Program Studi Ilmu Pemerintahan Fakultas Ilmu Sosial dan Ilmu Politik \\ Universitas Muhammadiyah Makassar \\ Jl. Sultan Alauddin No. 259 Makassar 90221 \\ Telp. 0411-866972 ext.107.Fax.0411-8655888 \\ Raman92@gmail.com, hamrun07@gmail.com \\ ${ }^{2}$ Program Studi Ilmu Administrasi Negara Fakultas Ilmu Sosial dan Ilmu Politik \\ Universitas Muhammadiyah Makassar \\ Jl. Sultan Alauddin No. 259 Makassar 90221 \\ Telp. 0411-866972 ext.107.Fax.0411-8655888 \\ Ihyani malik@yahoo.co.id
}

\begin{abstract}
This study aims to determine the shape of local government partnership with community groups in the management of mangrove forests in the village Tongke - Tongke of Sinjai Regency. The method used in this research is qualitative descriptive approach. The results showed that the form of partnership that exists is a form of pseudo -partnership or quasi partnership which is an alliance between two or more parties, but do not make it an equal partnership. Planting is done by the government and community groups in the mangrove forest management can be quite good and has the potential to achieve sustainable mangrove forest.
\end{abstract}

Keywords : partnership, mangrove forests, Tonke - Tongke

\begin{abstract}
ABSTRAK
Penelitian ini bertujuan untuk mengetahui bentuk kemitraan pemerintah daerah dengan kelompok masyarakat dalam pengelolaan Hutan Mangrove di Desa Tongke-tongke Kabupaten Sinjai. Metode yang digunakan dalam penelitian ini adalah pendekatan deskriptif kualitatif. Hasil penelitian menunjukkan bahwa bentuk kemitraan yang terjalin yaitu bentuk pseudo-partnership atau kemitraan semu yang merupakan sebuah persekutuan yang terjadi antara dua pihak atau lebih, namun tidak melakukan kerjasama secara sederajat. Penanaman yang dilakukan oleh pihak pemerintah dan kelompok masyarakat dalam pengelolaan hutan mangrove dapat dikatakan cukup baik dan berpotensi untuk mewujudkan hutan mangrove yang berkelanjutan.
\end{abstract}

Kata Kunci : Kemitraan, Hutan Mangrove, Tonke-Tongke 


\section{A. PENDAHULUAN}

Hutan mangrove merupakan salah satu dari kekayaan sumberdaya alam di Indonesia dan harus dikelola dengan baik. Kebijakan pengelolaan dimaksud, selanjutnya secara nasional telah diatur dalam Pasal 3 UndangUndang nomor 27 tahun 2007 tentang pengelolaan wilayah pesisir dan pulau-pulau kecil bahwa Pengelolaan Wilayah Pesisir dan Pulau-Pulau Kecil berasaskan: keberlanjutan, konsistensi, keterpaduan, kepastian hukum, kemitraan, pemerataan, peran serta masyarakat, keterbukaan, desentralisasi, akuntabilitas dan keadilan.

Hutan mangrove merupakan suatu ekosistem yang mempunyai peranan penting ditinjau dari sisi ekologis maupun aspek sosial ekonomi. Hutan mangrove adalah tipe hutan yang ditumbuhi dengan pohon bakau (mangrove) yang khas terdapat di sepanjang pantai atau muara sungai dan dipengaruhi oleh pasang surut air laut. Hutan mangrove mempunyai fungsi ganda dan merupakan mata rantai yang sangat penting dalam memelihara keseimbangan siklus biologi di suatu perairan. Sebagai suatu ekosistem dan sumberdaya alam, pemanfaatan mangrove diarahkan

Untuk kesejahteraan ummat manusia dan untuk mewujudkan pemanfaatannya agar dapat berkelanjutan, maka ekosistem mangrove perlu dikelola dan dijaga keberadaannya. Kerangka pengelolaan hutan mangrove terdapat dua konsep utama. Pertama, perlindungan hutan mangrove yaitu suatu upaya perlindungan terhadap hutan mangrove menjadi kawasan hutan mangrove konservasi. Kedua, rehabilitasi hutan mangrove yaitu kegiatan penghijauan yang dilakukan terhadap lahan-lahan yang dulu merupakan salah satu upaya rehabilitasi yang bertujuan bukan saja untuk mengembalikan nilai estetika, tetapi yang paling utama adalah untuk mengembalikan fungsi ekologis kawasan hutan mangrove yang telah ditebang dan dialihkan fungsinya kepada kegiatan lain. Walters (2008) menyatakan bahwa hutan mangrove di sepanjang pesisir pantai dan sungai secara umum menyediakan habitat bagi berbagai jenis ikan. Hutan mangrove sebagai salah satu lahan basah di daerah tropis dengan akses yang mudah serta kegunaan komponen biodiversitas dan lahan yang tinggi telah menjadikan sumberdaya tersebut sebagai sumberdaya tropis yang kelestariannya akan terancam dan menjadi salah satu pusat dari isu lingkungan global. Konversi hutan mangrove terus meningkat untuk dijadikan lahan pertanian atau tambak ikan/udang, sehingga menyebabkan penurunan produktivitas ekosistem tersebut. Salah satu daerah di Sulawesi Selatan yang masih memiliki hutan mangrove yang cukup luas adalah Kabupaten Sinjai.

$$
\text { Meningkatnya }
$$

kecenderungan

pengrusakan ekosistem hutan mangrove seiring dengan meningkatnya kebutuhan hidup masyarakat lokal seperti, penebangan pohon mangrove yang dijadikan kayu bakar untuk kebutuhan rumah tangga dan bara arang untuk diperdagangkan, tanpa memperhatikan daya dukung dan daya pulihnya, serta meningkatnya aktivitas pencari kepiting (pasodok) yang mencari kepiting ke wilayah ekosistem mangrove juga memicu peningkatan kerusakan hutan mangrove. Upaya pelestarian kembali hutan mangrove yang telah mengalami kerusakan beberapa waktu lalu, telah menjadi perhatian oleh masyarakat desa Tongke- Tongke, Kecamatan Sinjai Timur, Kabupaten Sinjai dengan melakukan penanaman kembali terhadap hutan mangrove yang rusak melalui swadaya masyarakat. Masalah berikutnya adalah penebangan secara liar baik digunakan sebagai kayu bakar, atau dijadikan arang untuk dijual, perluasan areal tambak secara tidak terkendali, sehingga apabila hal ini tidak segera dihentikan, maka suatu saat kita tidak melihat lagi hutan mangrove di Kabupaten Sinjai dan hal ini merupakan bencana besar.

Dalam pengelolaan hutan mangrove terdapat suatu bentuk kerja sama atau kemitraan pada esensinya adalah dikenal dengan istilah gotong royong atau kerjasama dari berbagai pihak, baik secara individual maupun kelompok. Menurut Notoatmodjo (2003), kemitraan adalah suatu kerja sama formal antara individu-individu, kelompokkelompok atau organisasi-organisasi untuk 
mencapai suatu tugas atau tujuan tertentu.

Prinsip kemitraan yang dijadikan dasar etika dalam bisnis dan kerjasama yang harus diperhatiakan bagi yang bermitra (Takbir, 2013) yaitu : (1) Karakter, integritas dan Kejujuran. Setiap orang hakekatnya memiliki karakter yang berbeda antara yang satu dengan yang lainnya, sehingga karakter itu menunjukkan kepribadian seseorang atau sekelompok komunitas tertentu. Seseorang yang memiliki karakte yang baik biasanya memiliki integritas diri yang tinggi dan memancarkan kewibawaan dan kejujuran yang lebih dari mereka yang memiliki integritas yang kurang. (2) Kepercayaan.

Seseorang yang akan bekerjasama dengan pihak atau orang lain tentunya harus memiliki mitra yang dapat dipercaya yang telah melalui proses uji kelayakan sebagai mitra, karena kepercayaan merupakan modal dalam berbisnis yang tidak muncul begitu saja atau secara dadakan, melainkan lahir dan dibangun dari pengalaman. Kepercayaan dimunculkan dari proses yang mungkin dari waktu yang singkat bahkan bias pula dari waktu yang lama. (3) Komunikasi yang terbuka. dikarenakan kerjasama didasarkan atas kepentingan kedua belah pihak, maka kerjasama harus ada komunikasi yang terbuka antara keduanya. Komunikasi kedua belah pihak penting, mengingat dalam bermitra memerlukan banyak informasi untuk menunjang kepentingan usaha bersama. Pertukaran informasi dan diskusi kedua pihak mengenai usaha bersama yang dijalankan tidak mungkin terjadi jika salah satu pihak menutup diri atau kurang terbuka. Oleh karena itu, komunikasi yang terbuka merupakan salah satu perinsip dasar bermitra yang harus dilakukan. (4) Dalam kerjasama tentunya harus ada keadilan dari kedua belah pihak. Artinya bahwa bila usaha yang dijalankan mengalami kerugian, maka bukan hanya satu saja pihak yang harus menanggung kerugian tersebut, dan begitupun sebaliknya. Dengan demikian adil menunjukkan sikap tidak berat sebelah atau menguntungkan/merugikan pihak lain.

Agar behasil melaksanakan kerjasama tersebut tentunya dengan saling memberikan manfaat antara pihak yang bermitra, Menurut Hafsah dalam Takbir, 2013) mengemukakan tentang manfaat yang diperileh dalam kemitraan, beberapa diantaranya yaitu ; (1) Kemitraan dapat meningkatkan produktfitas organisasi. (2) Kemitraan dapat membantu organisasi mencapai tujuan dengan lebih efesien. (3) Kemitraan menrangi reiko yang ditanggung oleh organisasi dengan membaginya. (4) Kemitraan dapat memberikan dampak social yang besar.

Setelah mengkaji berbagai uraian di atas maka penulis tertarik untuk melakukan penelitian dengan tujuan penelitian untuk mengetahui sejauh mana bentuk kemitraan pemerintah daerah dan kelompok masyarakat dalam pengelolaan hutan mangrove di Desa Tongke-Tongke Kecamatan Sinjai Utara Kabupaten Sinjai dan sejauh mana Pemahaman pemerintah dan masyarakat tentang kemitraan dalam pengelolaan hutan mangrove di desa Tongke-Tongke Kec, Sinjai Utara Kabupaten Sinjai.

\section{B. KONSEP KEMITRAAN}

Kemitraan pada esensinya adalah dikenal dengan istilah gotong royong atau kerjasama dari berbagai pihak, baik secara individual maupun kelompok. Menurut Notoatmodjo (2003) kemitraan adalah suatu kerja sama formal antara individu-individu, kelompok-kelompok atau organisasiorganisasi untuk mencapai suatu tugas atau tujuan tertentu. Ada berbagai pengertian kemitraan secara umum (Promkes Depkes RI) meliputi : Kemitraan mengandung pengertian adanya interaksi dan interelasi minimal antara dua pihak atau lebih dimana masingmasing pihak merupakan "mitra" atau "partner". Kemitraan adalah proses pencarian bentuk-bentuk kebersamaan yang saling menguntungkan dan saling mendidik secara sukarela untuk mencapai kepentingan bersama. Kemitraan adalah upaya melibatkan berbagai komponen baik sektor, kelompok masyarakat, lembaga pemerintah atau nonpemerintah untuk bekerja sama mencapai tujuan bersama berdasarkan atas kesepakatan, prinsip, dan peran masing- 
masing. Kemitraan adalah suatu kesepakatan dimana seseorang, kelompok atau organisasi untuk bekerjasama mencapai tujuan, mengambil dan melaksanakan serta membagi tugas, menanggung bersama baik yang berupa resiko maupun keuntungan, meninjau ulang hubungan masing-masing secara teratur dan memperbaiki kembali kesepakatan bila diperlukan Definisi Kemitraan Menurut Para Ahli. (Takbir, 2013)

Menurut Mariotti, mengungkapkan ada 6 prinsip kemitraan yang dijadikan dasar etika dalam bisnis dan kerjasama yang harus diperhatiakan bagi yang bermitra yaitu : Karakter, integritas dan Kejujuran Setiap orang hakekatnya memiliki karakter yang berbeda antara yang satu dengan yang lainnya, sehingga karakter itu menunjukkan kepribadian seseorang atau sekelompok komunitas tertentu. Seseorang yang memiliki karakte yang baik biasanya memiliki integritas diri yang tinggi dan memancarkan kewibawaan dan kejujuran yang lebih dari mereka yang memiliki integritas yang kurang. Kepercayaan. Seseorang yang akan bekerjasama dengan pihak atau orang lain tentunya harus memiliki mitra yang dapat dipercaya yang telah melalui proses uji kelayakan sebagai mitra, karena kepercayaan merupakan modal dalam berbisnis yang tidak muncul begitu saja atau secara dadakan, melainkan lahir dan dibangun dari pengalaman. Kepercayaan dimunculkan dari proses yang mungkin dari waktu yang singkat bahkan bias pula dari waktu yang lama. Komunikasi yang terbuka. Di karenakan kerjasama didasarkan atas kepentingan kedua belah pihak, maka kerjasama harus ada komunikasi yang terbuka antara keduanya. Komunikasi kedua belah pihak penting, mengingat dalam bermitra memerlukan banyak informasi untuk menunjang kepentingan usaha bersama. Pertukaran informasi dan diskusi kedua pihak mengenai usaha bersama yang dijalankan tidak mungkin terjadi jika salah satu pihak menutup diri atau kurang terbuka. Oleh karena itu, komunikasi yang terbuka merupakan salah satu perinsip dasar bermitra yang harus dilakukan. Adil. Dalam kerjasama tentunya harus ada keadilan dari kedua belah pihak. Artinya bahwa bila usaha yang dijalankan mengalami kerugian, maka bukan hanya satu saja pihak yang harus menanggung kerugian tersebut, dan begitupun sebaliknya. Dengan demikian adil menunjukkan sikap tidak berat sebelah atau menguntungkan/merugikan pihak lain. PolaPola Kemitraan Bentuk pola kemitraan sama pemerintah dengan swasta/masyarakat biasanya berupa kontrak kerja, tender penyediaan barang atau jasa, atau biasa juga berupa Bisnis Process Outsourcing, adapun model-model kemitraan yang dapat diadopsi antara lain : (Takbir, 2013). OperasiPemeliharaan Pada oprasi ini sektor publik menyewa sebuah organisasi swasta untuk mengerjakan satu ataupun lebih tugas ataupun pelayanan publik selama 5-7 tahun. Sektor publik masih sebagai penyedia pelayanan yang utama, sedangkan organisasi swasta mengerjakan pelayanan yang diserahkan kepada pihak luar oleh sektor publik. Secara umum, pemerintah menggunakan prosedur kompotitif untuk memilih pihak yang menyelenggarakan Service Contract. Pembelian tersebut harus didasarkan pada waktu pelaksanaan yang lebih singkat dan yang membutuhkan sumber daya yang sedikit . Bangunan Transfer Operasi (BTO) Bentuk kemitraan ini didesain untuk membawa investasi sektor swasta membangun infrastruktur baru, dimana sektor swasta akan membangun, membiayai dan mengoprasikan infratruktur baru dan system baru yang sesuai dengan standar penerintah. Tujuan dan Manfaat Kemitraan Agar behasil melaksanakan kerjasama tersebut tentunya dengan saling memberikan manfaat antara pihak yang bermitra, (Takbir, 2013) mengemukakan tentang manfaat yang diperileh dalam kemitraan, beberapa diantaranya yaitu : Kemitraan dapat meningkatkan produktfitas organisasi. Kemitraan dapat membantu organisasi mencapai tujuan dengan lebih efesien. Kemitraan menrangi reiko yang ditanggung oleh organisasi dengan membaginya. Kemitraan dapat memberikan dampak social yang besar. Model-Model Kemitraan

Model-model kemitraan berikut ini 
adalah diilhami oleh fenomena biologis. Untuk itilah kemudian penulis mencoba mengangkat fenomena biologis yang ada didalam khasanah kehidupan organisma kedalam diskusi kemitraan ini. Tentu saja ini merupakan pendapat yang bersifat sporadic yang masih perlu dilakukan pendalaman maupun penyempurnaan lebih lanjut (Sulistiayani, 2004).

Bertolak dari pemahaman akan dunia organisma baik yang bersel atau yang tidak kasat mata, maupun hewan yang dapat dilihat, maka kemitraan dibedakan menjadi: (Sulistiayani, 2004) Pseudo partnership, atau kemitraan semu. Mutualism partnership, atau kemitraan mutualistik.

Conjugation partnership, atau kemitraan melalui peleburan dan pengembangan.

Kemitraan semu adalah merupakan sebuah persekutuan yang terjadi antara dua pihak atau lebih, namun tidak sesungguhnya melakukan kerjasama secara seimbang satu dengan lainnya. Bahkan pada suatu pihak belum tentu memahami secara benar akan makna sebuah persekutuan yang dilakukan. Dan untuk tujuan apa itu semua dlakukan serta disepakati. Ada suatu yang unik dalam kemitraan semacam ini, bahwa kedua belah pihak atau lebih sama-sama merasa penting untuk melakukan kerjasama, akan tetapi pihak-pihak yang lain yang bermitra belum tentu memahami substansi yang diperjuangkan dan manfaatnya apa.

Kemitraan semu semacam ini tampak nyata terjadi pada pola pembangunan yang dilakukan pada jaman orde baru, yang sering disosialisasikan melalui slogan "pembangunan dari dan oleh pemerintah untuk rakyat". Rakyat yang berposisi sebagai mitra kerja pemerintah sesungguhnya tidak mengetahui apa makna atas semua ini, walaupun mereka yakin bahwa itu sangat penting.

Kemitraan mutualistik adalah merupakan persekutuan dua pihak atau lebih yang sama-sama menyadari aspek pentingnya melakukan kemitraan, yaitu untuk saling memberikan manfaat dan mendapatkan manfaat lebih, sehingga akan dapat mencapai tujuan secara lebih optimal. Berangkat dari pemahaman akan nilai pentingnya melakukan kemitraan, dua agen/organisasi atau lebih yang memiliki status sama atau berbeda, melakukan kerjasama. Manfaat antara pihakpihak yang bekerjasama dapat diperoleh, sehingga memudahkan dalam mewujudkan visi dan misinya, dan sekaligus saling menunjang satu dengan yang lain.

Kemitraan konjugasi adalah kemitraan yang dianalogikan dari kehidupan paramecium. Dua paramecium melakukan konjugasi untuk mendapatkan enerji dan kemudian terpisah satu sama lain, dan selanjutnya dapat melakukan pembelahan diri. Bertolak dari analogi tersebut maka organisasi, agen-agen, kelompok-kelompok atau perorangan yang memiliki kelemahan didalam melakukan usaha atau mencapai tujuan organisasi dapat melakukan kemitraan dengan model ini. Dua pihak dapat melakukan konjugasi dalam rangka mengingatkan kemampuan masing-masing.

\section{KONSEP PEMERINTAH DAERAH}

Istilah pemerintahan adalah suatu ilmu dan seni. Disebut sebagai suatu disiplin ilmu pengetahuan karena memenuhi syaratsyaratnya, yaitu dapat dipelajari dan diajarkan, memiliki objek material maupun formal, sifatnya universal, sistematis serta spesifik (khas) dan dikatakan sebagai seni, karena banyak pemimpin pemerintahan yang tanpa pendidikan pemerintahan mampu berkiat serta dengan kharismatik menjalankan roda pemerintahan. (Syafii dkk, 2002:11) uitsluitend bezighoudt met de studie van interneen externe werking van de structuren en prosessen. Ilmu pemerintahan adalah ilmu yang menggeluti studi tentang penunjukan cara kerja ke dalam dank ke luar struktur dan proses pemerintahan umum.

Berdasarkan dengan ilmu pemerintahan tersebut, Inu Kencana Syafiie memberikan definisi sebagai berikut: Ilmu Pemerintahan adalah ilmu yang mempelajari bagaimana menyeimbangkan pelaksanaan kepengurusan (eksekutif), kepengurusan (legislatif), kepemimpinan dan koordinasi pemerintahan (baik pusat dengan daerah maupun rakyat dengan pemerintahannya) dalam berbagai 
peristiwa dan gejala pemerintahan, secara baik dan benar.

\section{KONSEP KELOMPOK MASYARAKAT}

Kelompok masyarakat adalah suatu kesatuan sosial yang terdiri dari dua atau lebih individu yang telah mengadakan interaksi sosial yang cukup intensif dan teratur sehingga diantara individu itu sudah terdapat pembagian tugas, struktur, dan norma-norma tertentu. Sedangkan Menurut Newcomb, Turner dan Converse kelompok masyarakat adalah Sejumlah orang-orang, dilihat sebagai kesatuan tuggal, merupakan satu kelompok sosial, tetapi kita terutama mempunyai perhatian terhadap interaksi kelompok dan terhadap cirri-cirinya yang relative stabil. Menurut (Ife dan Tesoriero 2008: 580) Peningkatan kesadaran Sebuah proses peningkatan kesadaran telah digambarkan dalam bab-bab terdahulu, dan disini tidak perluh untuk melihat kembali haltersebut secara mendetail.

Bagaimanapun, penting halnya untuk menekankan bahwa hal tersebut merupakan sebuah peran yang sangat penting bagi seorang pekerja pengembangan masyarakat karena meliputisemua aspek praktis. Salah satu karakteristik peningkatan kesadaran adalah bahwa ia sebaiknya dimaksudkan untuk memberikan kesadaran terhadap berbagai struktur dan strategi perubahan sosial hingga orang-orang dapat berpartisipasi dan mengambil tindakan efektif.

Dalam beberapa kasus strukturstruktur ini mungkin penting untuk membantu orang-orang dalam melihat bagaimana mereka bisa mendirikan berbagai struktur oleh diri mereka sendiri. Terkadang hal itu bisa dilakukan dengan hanya membantu orangorang untuk mengetahui berbagai cara yang mereka bisa mengubah kehidupan mereka sendiri, sehingga mereka tidak memberikan kontribusi atau memperkuat berbagai struktur memberikan informasi hanya dengan memberikan informasi yang relevan pada penduduk kelompok masyakat bisa melakukan suatu peran yang bermanfaat. Hal ini luas sekali cakupannya. Satu wilayah penting adalah informasi demogratis dan berbagai penunjuk sosial seperti struktur umum, angka bunuh diri, angka kriminalitas anak muda, distribusi pemasukan dan asal usul kesukuan semua hal ini dapat digunakan untuk membangun sebuah profil masyarakat. Informasi ini merupakan hal yang sangat penting bagi sebuah masyarakat dalam merencanakan berbagai cara yang paling baik untuk memenuhi kebutuhannya, dan bagaimana melibatkan penduduk sebanyak mungkin dalam berbagai proses pengembangan masyarakat. Hal tersebut dapat membantu menyoroti apa yang spesial atau bebeda mengenai masyarakat itu, dan dimana perbedaan dari angka nasional.

Kelompok masyarakat juga akan berada dalam suatu posisi yang baik untuk memberikan informasi mengenai berbagai program dalam masyarakat-masyarakat yang lain; seseorang harus berhati-hati dalam metransfer sebuah program-program yang sukses dari satu tempat yang lain, karena beragam sosial lokal, budaya dan politik, namun hal tersebut masih penting bagi orangorang untuk memiliki beberapa ide mengenai bagaimana berbagi hal dekerjaka ditempat lain dengan begitu mereka dapat belajar dari kesuksesan dan kegagalan masyarakat yang lain. Informasi mengenai berbagai sumber eksternal, seperti berbagai petunjuk pembiayaan, keahlian, berbagai pedoman, berbagai prestasi audio-visual dan berbagai paket pelatihan, adalah wilayah lainyang secara mudah memberikan informasi kepada penduduk tentang apa yang dapat menjadi sebuah layanan penting kerja masyarakat.

Prinsip kepercayaan diri menuntut seseorang pekerja untuk berhati-hati untuk tidak mengabaikan berbagai sumber loka, namun dengan kehati-hatian ini, masih penting bagi berbagai masyarakat untuk mampu menggunakan berbagai sumber eksternal yang pantas. Sering kali layak bagi kelompok masyarakat untuk mengimformasikan sebuah masyarakat tentang keadaan ekonomi atau realitas politik yang perluh mereka hubungi. Terkadang para anggota masyarakat dengan sendirinya akan sadar dengan hal ini, namun dalam sebuah masyarakat yang orangorangnya memiliki akses terbatas untuk memanfaatkan berbagai sumber, yang orang- 
orangnya telah memilih sebuah gaya hidup terisolasi atau suatu masyarakat yang terpenjara oleh berbagai kepentingan yang sangat kuat, penting bagi seorang pekerja masyarakat untuk mampu mengimformasikan penduduk mengenai berbagai hal yang mungkin secara langsung atau tidak langsung memengaruhi mereka. Seorang pekerja masyarakat bisa jadi yang pertama mengetahui, contohnya, bahwa seorang employer daerah sedang mempertimbangkan sebuah pembangunan pabrik, dan sebuah jalan raya lingkar yang ditawarkan akan memotong membelah masyarakat jadi dua.

\section{E. KONSEP PENGELOLAAN EKOSISTEM MANGROVE}

Ekosistem mangrove sangat produktif dan tidak bisa tergantikan. Karena itu, pengelolaan ekosistem tersebut harus mempertimbangkan berbagai faktor, tidak sekedar keuntungan ekonomi jangka pendek, sebagaimana konversi ekosistem mangrove untuk tambak (Kordi, 2012). Pengelolaan ekosistem mangrove adalah untuk kepentingan manusia, maka faktor-faktor terkait kepentingan tersebut harus dipertimbangkan. Juga tidak hanya satu faktor saja, tetapi harus secara keseluruhan untuk menghindari gesekan kepentingan yang satu dan lainnya. Faktor-faktor penting tersebut adalah ekologo, ekonomi, dan sosial budaya.

Sebagaimana telah disebutkan disebutkan di muka, bahwa pengelolaan ekosistem mangrove adalah untuk kepentingan manusia. Kerusakan dan kepunaham ekosistem mangrove akan berdmpak pada ekosistem laiannya, dan dampak terbesarnya adalah pada kehidupan manusia, baik sosial, ekonomi maupun politik. Ekosistem mangrove menyuplai bahan bangunan, bahan bakar, bahan pangan dan obat-obatan yang cukup besar untuk umat manusia. Ekosistem mangrove juga merupakan pelindung pantai dari abrasi yang diakibatkan oleh gelombang pasang maupun tsunami. Di samping itu, ekosistem mangrove merupakan salah satu tempat rekreasi dan pengembangan ilmu dan teknologi.
Karena itu, pengelolaan ekosistem mangrove tentu diupayakan untuk melestarikan ekosistem tersebut, menyediakan pangan dan obata-obatan, bahan bangunan dan kayu bakar, pengembangan daerah rekreasi, pengembangan ilmu teknologi, karena penduduk pesisir dan pulaupulau yang sebagainya bergantung pada ekosistem mangrove dan ekosistem pesisir lainnya tergolong masyarakat miskin, maka pengelolaan ekosistem mangrove adalah bagian dari upaya meningkatkan taraf hidup masyarakat tersebut.

Saat itu, hutan mangrove juga sudah mendapat perhatian. Sejak tahun 1991, Indonesia resmi menjadi anggota "Ramsar Convention". Lahan basah yang dimaksud dalam konvernsi itu adalah daerah-daerah payau, tanah gambus, atau perairan, baik yang bersifat alam maupun buatan, tetap ataupun sementara, dengan perairannya yang tergenang tatau mengalir, tawar, agak asin, maupun asin, termasuk daerah-daerah air surut. Hutan mangrove termasuk dalam pengertian lahan basah ini.

Area perlindungan mangrove, baik berupa taman nasional, Cagar Alam, Taman Baru, Taman Hutan Raya, Hutan Rekreasi, maupun Suaka Margasatwa, yang berada diwilayah pesisir serta pulau-pulau kecil yang memiliki potensi mangrove dijamin secara hukum, namun kenyataannya akupasi ekosistem mangrove terus berlangsung, termasuk di daerah-daerah yang dilindungi. Bahwa dari 50 tahun Nasional yang ditetapkan di Indonesia, hanya 22 diantaranya yang didentifikasi memiliki mangrove dengan luas yang memadai. Pada tahun 1997 tercatat sebanyak 64 areal perlindungan mangrove dan sekarang jumlah itu terus bertambah, demikian juga luasnya.

Penanaman tanaman mangrove sebaiknya dilakukan pada saat air laut surut agar mudah mengatur jarak dan keseragamannya. Untuk lokasi penanaman yang terletak dibibir laut terbuka, penanaman tidak dilakukan pada musim ombak besar. Ini dimaksudkan agar benih tidak hanyut terbawa ombak. Di samping itu, untuk mencegah tanaman terbawa ombak, maka pada benih 
mangrove yang ditanam di bibir laut terbuka harus dilindungi dengan bius atau goronggorong serta alat penahan ombak.

Sebelum penanaman

perlu dipersiapkan peralatan yang digunakan. Peralatan tersebut antara lain (Kordi, 2012) tali pengatur jarak, yang digunakan untuk mengatur jarak antar tanaman serta jalur tanaman menjadi lurus. Tali pengatur jarak dapat berupa tali raffia / plastik atau tali lainnya yang berukuran panjang 10-20 m. Kedua ujung tali ini diikat dengan sepotong bamboo atau kayu dan pada jarak tanam yang diinginkan diberi tanda (cat atau tali plastik yang diikat) sebagaib titik penanaman. Ajir, yakni digunakan untuk penanaman pada pantai yang menhadap lauk lepas yang ombaknya cukup besar. Beni diikat keajir agar tidak hanyut di bawa ombak. Ajir juga dapat digunakan untuk penanaman disungai atau saluran air sebagai tanda adanya tanaman baru. Ajir dapat dibuat dari kayu atau bambu. Tugal atau suwan, yaitu diguanakan untuk membutat lubang tanaman dan dibutuhkan sewaktu menanam ditanah lumpur yang agak keras. Tugal dapat dibuat dari kayu atau bambu bulat. Ember dan parang. Ember diguanakan untuk mengangkut benih pada saat penanaman, sedangkan parang digunakan untuk membersihkan tumbuhan liar atau ranting.

Rehabilitasi ekosistem mangrove sudah dimulai sejak tahun 1980-an, terutama diinisiasi oleh penduduk pesisir dan pulaupulau. Mereka menanam tumbuhan tumbuhan mangrove untuk mencegah abrasi pantai oleh gelombang pasang yang menjangkau dan merusak rumah-rumah mereka. Ketika beberapa orang menenam mangrove, mereka dicibir sebagai orang gila atau tidak ada kerjaan. Namun setelah beberapa tahun, tumbuhan mangrove yang ditanam mulai berfungsi dan dirasakan manfaatnya, barulah penduduk beramai-ramai menanam mangrove. Para inisiator yang dicap gila pun berubah menjadi orang yang sangat berjasa sebagai pahlawan.

Saat ini, rehabilitasi mangrove melalui penanaman kembali ekosistem mangrove yang rusak telah menjadi program nasional, yang didukung oleh dunia internasional. Bahkan sejak tahun 2005, penanaman mangrove mengalami peningkatan yang luar biasa, ini dipicuh oleh tsunami yang meluluhlantakkan Aceh dan Nias pada 24 Desember 2004. Beberapa korban yang selamat dari hantaman gelombang tsunami karena tersangkut dipohon mangrove, atau bangunan tetap berdiri utuh karena terlindung dari ekosistem mangrove atau hutan pantai lainnya. Studistudi juga membuktikan bahwa ekosistem mangrove dan hutan pantai sangat andal dalam melindungi pantai dan bangunan dari gelombang pasang maupun tsunami. Penyebab Kerusakan Ekosistem Mangrove (Kordi, 2012).

Penyebab kerusakan ekosistem mangrove disebabkan oleh banyak factor, baik berdiri sendiri, tumpang tindih maupun saling mendukung. Pengambilan kayu, baik untuk kontruksi bangunan, kayu bakar dan produksi arang dilakukan oleh masyarakat miskin. Harga kayu bakar yang tinggi mengikuti tinggi harga dan hilangnya minyak tanah mendorong okupasi ekosistem mangrove untuk kayu bakar, di sisi lain lemahnya penegakan hukum menjadi factor penyebab kerusakan ekosistem mangrove yang tumpang tindih.

\section{F. METODE PENELITIAN}

Lokasi penelitian akan dilaksanakan di Desa Tongke-Tongke Kecamatan. Sinjai Timur Kabupaten Sinjai, dengan pertimbangan bahwa pengelolaan hutan mangrove perlu mendapatkan perhatian dari semua kalangan yang terkait. Jenis penelitian yang digunakan adalah pendekatan deskriptif kualitatif, yaitu dimaksudkan untuk pengukuran yang cermat terhadap studi kasus fenomena sosial tertentu. Sumber data penelitian ini terutama disaring dari sumber data primer dan data sekunder dengan proporsi sesuai dengan tujuan penelitian ini. Dalam penelitian ini yang akan dijadikan informan adalah istansi yang terkait, dan kelompok manyarakat Aku Cinta Indonesia (ACI) desa Tongke-Tongke. Untuk memperoleh data yang relevan sebagaimana yang diharapkan dalam tujuan penelitian, maka digunakan teknik pengumpulan data. 
Observasi (pengamatan), dan Dokumentasi. Analisis data dilakukan dengan menelaah data yang diperoleh dari berbagai sumber atau informasi dari hasil penelitian kemitraan pemerintah daerah dengan kelompok masyarakat dalam pengelolaan hutan mangrove. baik yang diperoleh melalui data primer maupun data sekunder yang dilakukan secara deskriftif kualitatif dengan didukung tabel frekuensi yang sederhana dan didukung beberapa variabel pendukung yang dijadikan indikator dalam penelitian ini. Setelah menganalisis data, peneliti harus memastikan apakah interpretasi dan temuan penelitian akurat. Member checking adalah proses penelitian mengajukan pertanyaan pada satu atau lebih partisipan atau tujuan seperti yang telah dijelaskan di atas. Aktifitas ini juga dilakukan untuk mengambil temuan kembali pada partisipan dan menanyakan pada mereka baik lisan maupun tulisan tentang keakuran laporan penelitian.

\section{G. HASIL DAN PEMBAHASAN}

Bentuk-bentuk kemitraan berikut ini adalah diilhami oleh fenomena biologis. Untuk itilah kemudian penulis mencoba mengangkat fenomena biologis yang ada didalam khasanah kehidupan organisma kedalam diskusi kemitraan ini. Tentu saja ini merupakan pendapat yang bersifat sporadic yang masih perlu dilakukan pendalaman maupun penyempurnaan lebih lanjut (Sulistiayani 2004).

Bertolak dari pemahaman akan dunia organisma baik yang bersel atau yang tidak kasat mata, maupun hewan yang dapat dilihat, maka kemitraan dibedakan menjadi: (Sulistiayani, 2004) Pseudo partnership, atau kemitraan semu. Mutualism partnership, atau kemitraan mutualistik. Conjugation partnership, atau kemitraan melalui peleburan dan pengembangan. Kemitaan semu adalah merupakan sebuah persekutuan yang terjadi antara dua pihak atau lebih, namun tidak sesungguhnya melakukan kerjasama secara seimbang satu dengan lainnya. Bahkan pada suatu pihak belum tentu memahami secara benar akan makna sebuah persekutuan yang dilakukan. Dan untuk tujuan apa itu semua dlakukan serta disepakati. Ada suatu yang unik dalam kemitraan semacam ini, bahwa kedua belah pihak atau lebih sama-sama merasa penting untuk melakukan kerjasama, akan tetapi pihak-pihak yang lain yang bermitra belum tentu memahami substansi yang diperjuangkan dan manfaatnya apa.

\section{Penanaman Mangrove}

Kegiatan penanaman mangrove mencakup penentuan lokasi penanaman, pemilihan jenis pada setiap tapak, persiapan lahahn, dan cara penanaman. Lokasi penanaman mangrove biasanya dilakukan ditepi pantai yang mengandung substrak lumpur, tepian sungai yang masih terpengaruh air laut, dan tanggul saluran air tambak. Pemilihan jenis pada setiap tapak perlu dilakukan agar bibit dapat tumbuh dengan baik. Seperti bakau (Rhizophara spp). Dapat tumbuh dengan baik pada substrak (tanah) yang berlumpur, dan dapat mentolerangsi tanah lumpur berpasir, di pantai yang agak berombak dengan frekuensi genangan 20-40 kali/bulan. Bakau merah dapat ditanam pada lokasi bersubstrak (tanah) pasir berkoral.

Penanaman tanaman mangrove sebaiknya dilakukan pada saat air laut surut agar mudah mengatur jarak dan keseragamannya. Untuk lokasi penanaman yang terletak dibibir laut terbuka, penanaman tidak dilakukan pada musim ombak besar. Ini dimaksudkan agar benih tidak hanyut terbawa ombak. Di samping itu, untuk mencegah tanaman terbawa ombak, maka pada benih mangrove yang ditanam di bibir laut terbuka harus dilindungi dengan bius atau goronggorong serta alat penahan ombak.

Data yang dihimpun dari informan untuk variabel penanaman mangrove dengan indikator penanaman mangrove yang jelas tampak pada jawaban informan tersebut. Berikut hasil kutipan wawancara dengan beberapa informan terkait dengan penanaman mangrove berikut ini:

"Dalam penanaman hutan mangrove di Desa Tongke-Tongke yaitu bagaimana pihak pemerintah memfasilitasi 
kebutuhan masyarakat berupa bantuan bibit mangrove, biaya pengangkutan sampai upah penanaman mangrove". (wawancara, $R H$ ).

Berdasarkan hasil wawancara dengan pihak Pemeritah oleh Dinas Perkebunan dan kehutanan di desa Tongke-tongke Kecamatan Sinjai Timur Kabupaten Sinjai. Bahwa penanaman hutan mangrove selaku pihak pemerintah dinas pekebunan dan kehutanan yaitu memberikan fasilitas kepada masyarakat berupa bibit mangrove sebanyak 50.000 batang bibit pada tahun 2011. Dengan memberikannya fasilitas bibit mangrove terhadap masyarakat dapat memberikan kemudahan dalam pengelolaaan hutan mangrove di Desa tongke-tongke selain itu ini menjadi suatu kerjasama oleh Pemeritah Dinas Perkebunan dan kehutanan dengan kelompok masyarakat. Terjalinnya suatu kerjasama memberikan dampak positif terhadap pelestarian hutan mangrove seperti dengan konsep hutan mangrove itu sendiri bahwa Ekosistem mangrove merupakan ekosistem yang sangat produktif, karena selain merupakan habitat berbagai biota, ekosistem tersebut pun merupakan daerah pemijatan, pengasuhan, dan tempat mencari makanan berbagai biota sekitrnya. Karena itu, ekosistem mangrove merupakan ekosistem yang mendukung kehidupan pesisir, laut, dan darat. Produksi perikanan tangkap dipesisir dan laut sangat bergantung pada ekosistem mangrove. Ekosistem mangrove juga melindungi daratan dari industri garam dan gelombang, termasuk tsunami, juga melindungi pesisir dan laut dari limpasan air tawar, dan limbah.

Dapatlah dikatakan bahwa dalam penanaman hutan mangrove oleh Dinas Perkebunan dan Kehutanan berperan penting dalam melakukan penanaman dan pelestarian hutan mangrove dengan adanya mitra kerja yang dilakukan oleh pemerintah Dinas Perkebunan dan Kehutanan dengan masyarakat setempat di Desa Tongke-Tongke Kabupaten Sinjai.

"Menghimbau masyarakat agar
melakukan penanam terus-menerus
mangrove, menjaga, memelihara dengan

baik agar pemukiman ini tetap terlindungi dari abrasi dan angin kencang" (wawancara, AK).

Berdasarkan hasil wawancara dengan informan pihak Pemeritah oleh Kepala Desa Tongke-Tongke Kecamatan Sinjai Timur Kabupaten Sinjai. Menghimbau masyarakat agar melakukan penanam terus-menerus mangrove, menjaga,dan memelihara dengan baik agar pemukiman ini tetap terlindungi dari abrasi dan angin kencang. Dengan adanya himbauan pemerintah setempat, masyarakat melakukan penanaman secara swadaya dan membawa perubahan yang sangat dirasakan manfaatnya seperti Pemukiman telah bebas dari genangan air pasang dan gempuran ombak yang besar, tidak terjadi lagi pengikisan pantai sehingga ekosistem mangrove dapat terjamin.

Ekosistem mangrove sangat produktif dan tidak bisa tergantikan. Karena itu, pengelolaan ekosistem tersebut harus mempertimbangkan berbagai factor, tidak sekedar keuntungan ekonomi jangka pendek, sebagaimana konversi ekosistem mangrove untuk tambak. Karena itu, pengelolaan ekosistem mangrove tentu diupayakan untuk melestarikan ekosistem tersebut, menyediakan pangan dan obata-obatan, bahan bangunan dan kayu bakar, pengembangan daerah rekreasi, pengembangan ilmu teknologi, karena penduduk pesisir dan pulaupulau yang sebagainya bergantung pada ekosistem mangrove dan ekosistem pesisir lainnya tergolong masyarakat miskin, maka pengelolaan ekosistem mangrove adalah bagian dari upaya meningkatkan taraf hidup masyarakat tersebut. Dapatlah dikatakan bahwa dengan adanya himbauan dalam penanaman hutan mangrove oleh Kepala Desa Tongke-Tongke berperan penting dalam melakukan penanaman dan pelestarian hutan mangrove dengan adanya mitra kerja yang dilakukan oleh Kepala Desa dengan masyarakat setempat di Desa Tongke-Tongke Kabupaten Sinjai. 


\section{Konservasi Hutan Mangrove}

Perlindungan pada
proses ekologi beserta
sistem-sistem
penyangga kehidupan.
keanekaragaman sumber plasma nutfah yang
dilakukan didalam dan diluar kawasan, serta
pengaturan memberikan status perlindungan
data yang dihimpun dari informan untuk
variabel konservasi hutan mangrove dengan
indikator konservasi hutan mangrove yang
jelas tampak pada jawaban informan tersebut.
Berikut hasil kutipan wawancara dengan
beberapa informan terkait dengan konservasi
hutan mangrove berikut ini:

"dalam bentuk kenservasi pemerintah melarang masyarakat agar tidak melakukan penebangan hutan mangrove karena pelestariannya yang kita harus jaga." (wawancara, AK).

Berdasarkan hasil wawancara dengan informan pihak Pemeritah oleh Kepala Desa Tongke-Tongke Kecamatan Sinjai Timur Kabupaten Sinjai. Bahwa Dalam bentuk kenservasi pemerintah melarang masyarakat agar tidak melakukan penebangan hutan mangrove karena pelestariannya yang kita harus jaga. Dengan melakukan konservasi hutan mangrove ekosistem lingkungan mangrove akan terjaga kelestariaannya serta dengan banyakanya dampak positif yang dirasakana oleh masyarakat itu sendiri seperti dalam konsep konservasi hutan mangrove itu dijelaskan Perlindungan terhadap kelansungan proses ekologi beserta sistem-sistem penyangga kehidupan. Pengawetan keanekaragaman sumber plasma nutfah yang dilakukan didalam dan diluar kawasan, serta pengaturan memberikan status perlindungan, kawasan konservasi dibagi kedalam zona-zona tertentu. Dalam himbauan konservasi yang dilakukan oleh pemerintah desa Tongke tongke memberikan pengaruh besar dalam menunjang dan melestarikan ekositem mangrove. Konservasi hutan mangrove memberikan cerminan bagaimana kita mampu menjaga keseimbangan ekologi.

\section{Rehabilitasi Hutan Mangrove}

Rehabilitasi mangrove melalui penanaman kembali ekosistem mangrove yang telah rusak, terutama diinisiasi oleh penduduk pesisir dan pulau-pulau. Mereka menanam tumbuhan-tumbuhan mangrove untuk mencegah abrasi pantai oleh gelombang pasang yang menjangkau dan merusak rumahrumah mereka. Data yang dihimpun dari informan untuk variabel rehabilitasi hutan mangrove dengan indikator Rehabilitasi Hutan Mangrove yang jelas tampak pada jawaban informan tersebut. Berikut hasil kutipan wawancara dengan beberapa informan terkait dengan rehabilitasi hutan mangrove berikut ini:

"Dalam rehabilitasi hutan mangrove yang kami lakukan selaku pemerintah dinas perkebunan dan kehutanan memberikan fasilitas berupa bantuan bibit, biaya perawatan dan upah penanaman yang dilakukan masyarakat dalam merehabilitasi hutan mangrove yang telah rusak" (wawancara, $R H$ ).

Berdasarkan hasil wawancara yang dilakukan oleh kepala dinas perkebunan dan kehutanan Kabupaten Sinjai mengenai hal rehabilitasi hutan mangrove tahun 2004 pihak pemerintah memberikan fasilitas bantuan berupa bibit rehabilitasi seluas 25 ha dan bibit yang diberikan sebanyak 5000 batang bibit/hektar. biaya perwatan dan upah penanaman yang dilakukan masyarakat dalam merehabilitasi hutan mangrove yang telah rusak, ini menunjukan bahwa pemerintah sadar betul bagimana rehabilitasi hutan mangrove yang sebaiknya, dengan memberikannya bantuan tersebut memunjukan pemerintah terjung langsung dan berperang sepenuhnya dalam pengelolaan hutan mangrove agar dapat semakin berkembang seperti dalam konsep rehabilitasi bertujuan untuk memulihkan kondisi ekosistem mangrove yang telah rusak agar ekosistem mangrove dapat menjalangkan kembali fungsinya dengan baik. Upaya 
rehabilitasi harus melibatkan seluruh lapisan masyarakat yang berhubungan dengan kawasan mangrove. Rehabilitasi kawasan mangrove dilakukan sesuai dengan manfaat dan fungsi yang seharusnya berkembang, serta aspirasi.

Kemitraan biasanya didefinisikan sebagai hubungan sukarela dan bersifat kerja sama antara beberapa pihak, baik pemerintah maupun swasta, yang semua orang didalamnya setuju untuk bekerja sama dlam meraih tujuan bersama dan menunaikan kewajiban tertentu serta menanggung resiko, tanggung jawab, sumber daya, kemampuan dan keuntungan secara bersama sama. Kunci utama terlaksananya kemitraan adalah dengan menerapkan koordinasi, integrasi dan sinkronisasi seluruh program-program dengan lembaga-lembaga terkait yang berpartisipasi dalam kemitraan tersebut.

Berikut hasil kutipan wawancara terhadap informan Dinas perkebunan dan kehutanan pemerintah daerah dengan kelompok masyarakat tentang kemitraan dalam pengelolaan hutan mangrove di Desa Tongke-Tongke Kecamatan Sinjai Timur Kabupaten Sinjai seperti berikut ini :

"Pemahaman dinas perkebunan dan kehutanan tentang kemitraan itu bagaimana dinas perkebunan dan kehutanan menfasilitasi masyarakat sesuai dengan kebutuhan karena masyarakat yang menerima program kalau kita punya program, sasarannya bagaimana intinya itu mangrove bisa lebih baik" (Wawancara, RH).

Dari pernyataan diatas selaku Dinas perkebunan dan kehutanan tentang pemahaman kemitraan selaku dinas yang terkait dengan memberikan fasilitas masyarakat terhadap program pengelolaan hutan mangrove dapat memberikan manfaat terhadap semua kalangan terutama pada lingkunagan masyarakat sekitar kawasan hutan mangrove. Dalam kedudukan ekosistem mngrove di dalam lingkungan alam tidak berdiri sendiri, melainkan merupakan bagian ekosistem yang lebih luas. Brown (1984) mendeskripsikan mangrove sebagai ekosistem interflace atau ekosistem peralihan yang menempati daerah perbatasan antara laut dan daratan. Fungsi utama ekosistem mangrove, yaitu: (1) fungsi fisik, pencegah abrasi, perlindungan terhadap angin, pencegah intrusi garam dan sebagai penghasil energi serta hara; (2) fungsi biologis, meliputi: sebagai tempat bertelur dan sebagai asuhan berbagai biota, tempat bersarang burung dan sebagai habitat alami berbagai biota; (3) fungsi ekonomis meliputi: sebagai sumber bahan bakar (kayu bakar dan arang), bahan bangunan (balok, atap dan sebagainya), perikanan, pertanian, makanan, minuman, bahan baku kertas, keperluan rumah tangga, tekstil, serat sintesis, penyamakan kulit, obatobatan, dan lain-lain.

Dengan dipahaminya fungsi hutan mangrove seperti dalam konsep diatas sebagai pihak terkait memberikan keseriusan dalam melakukan pengelolaan hutan mangrove supaya terjadinya balances antara ekologi lingkungan dan lingkungan masyarakat itu sendiri.

"Pemahaman saya tentang kemiraan dalam pengelolaan hutan mangrove di Desa Tongke-Tongke itu sangat baik karena memicu tentang pemberdayaan masyarakat dan pelestarian lingkungan itu sendiri". (wawancara, AK).

Dari pernyataan informan diatas terkait dengan konsep kemitraan bahawa selaku pemerintah desa tongke-tongke dengan adanya kemitraan menurut informan itu sangat baik karena memicu tentang pemberdayaan masyarakat dan pelestarian lingkungan itu sendiri dengan adanya kemitraan dilakukan oleh yang terkait tersebut memberikan suatu manfaat besar baik diakalangan pemerintah maupun masyarakat. Dengan dukungan pemerintah tersebut masyarakat terdorong untuk melakukan pengelolaaan hutan mangrove. Dengan adanya kemitraan atau kerjasama yang dilakukan oleh yang terkait, untuk memudahkan mencapai tujuan secara bersama. Dengan tercapainya tujuan yang dikehendaki secara bersama memberikan suatu manfaat yang positif bagi semua kalangan. 


\section{H. PENUTUP}

Bentuk kemitraan pemerintah daerah dengan kelompok masyarakat dalam pengelolaan hutan mangrove di Desa TongkeTongke Kecamatan Sinjai Timur Kabupaten Sinjai adalah Pseudo partnership, atau kemitraan semu yang merupakan sebuah persekutuan yang terjadi antara dua pihak atau lebih, namun tidak sesungguhnya melakukan kerjasama secara seimbang satu dengan lainnya. Bahkan pada suatu pihak belum tentu memahami secara benar akan makna sebuah persekutuan yang dilakukan. Dan untuk tujuan apa itu semua dlakukan serta disepakati; (1) berdasarkan hasil pengamatan penulis bahwa penanamana hutan mangrove di desa tongke-tongke terlaksana dengan baik walaupun kemitraan yang terbentuk hanyalah kemitraan semu antara pihak-pihak yang terkait dalam melakukan suatu pengelolaan hutan mangrove. (2) konservasi dengan indikator bentuk-bentuk konservasi pengelolaan hutan mangrove sangat baik karena masyarakat dan kelompok ACI menjaga kelestarian hutan mangrove dengan kesadaran yang secara bersama dengan tujuan yang sama. (3) Rehabilitasi terhadap pengelolaan hutan mangrove pihak masyarakat dan kelompok terkait melakukan penanaman kembali hutan yang mengalami krusakan dan melakukan prawatan pada setiap mangrove.

Pemahaman Pemerintah dengan Kelompok masyarakat tentang kemitraan dalam pengelolaan hutan mangrove tidaklah begitu memahami karena dimana kemitraan itu adalah suatu kesepakatan antara seseorang, kelompok atau organisasi untuk bekerja sama mencapai tujuan. Namun kemitraan antara pemerintah dinas kehutanan dan perkebunan dengan kelompok masyarakat tidak mempunyai kesepakatan secara tertulis antara keduanya dalam melakukan kemitraan.
Kordi. 2012. Ekosistem Mangrove, Potensi, Fungsi, dan Pengelolaan. Jakarta : Rineka Cipta.

Hurairah, Abu. 2008. Pengorganisasian dan Pengembangan Masyarakat. Bandung : Humaniora

Ife, Jim dan Tesoriero, 2008. Community Development: Alternatif Pengembangan Masyrakat di Era Globalisasi. Yogyakarta : Pustaka Pelajar,.

Supriharyono. 2000. Pelestarian dan Pengelolaan Sumber Daya Alam di Wilaya Pesisir Tropis, Jakarta : Gramedia Pustaka Utama.

Sulistiyani, Teguh Ambar, 2004. Kemitraan dan Model-Model Pemberdayaan, Yogyakarta : Gava Media.

Tarigan, M. S. 2008. Sebaran dan luas hutan mangrove di Wilayah Pesisir Teluk Pising Utara Pulau Kabaena Provinsi Sulawesi Tenggara. LIPI, Jakarta : Makara Sains.

Takbir, Mohammad. 2013. Kemitraan Pemerintah Pusat Dan Pemerintah Daerah Dalam Pengelolaan Taman Nasional Komodo Di Kabupaten Manggarai Barat Provinsi Nusa Tenggara Timur. Skripsi, universitas muhammadyiah makassar.

\section{DAFTAR PUSTAKA}

Arief, A. 2003. Hutan Mangrove, Fungsi dan Manfaatnya. Yogyakarta : Kanisius. 